\title{
EM DEFESA DA DIÁSPORA AFRICANA
}

\section{IN DEFENSE OF AFRICAN DIASPORA}

Marcos Rodrigues

http://orcid.org/0000 0002-6662-2350

Universidade Federal da Bahia

jmbr.ba@gmail.com

\section{DOI: 10.22481/odeere.v5i9.6502}

RESUMO: Resenha do livro SILVA, Maria Alice Pereira da. Pedra de Xangô: um lugar sagrado afrobrasileiro na cidade de Salvador. Recife: Liceu, 2019. 157 p.

Palavras-chave: Pedra de Xangô; Sagrado; Afro-Brasileiro

ABSTRACT: Book review SILVA, Maria Alice Pereira da. Pedra de Xangô: a sacred Afro-Brazilian place in the city of Salvador. Recife: Liceu, 2019. 157 p.

Keywords: Pedra de Xangô; Sacred; Afro-Brazilian

O livro que acabo de ler simboliza uma ação em defesa da Pedra de Xangô, ou ainda, em defesa das poucas áreas verdes restantes na capital baiana. O texto traz uma discussão sobre os vários eixos que implicam a diáspora africana na Bahia, em busca da compreensão de uma cultura dispersa e negociada. Também, tece questões sobre o crescimento da cidade de Salvador a partir da ocupação colonizadora em um passado histórico nebuloso, visível apenas aos olhos hipotéticos das ciências sociais, humanas e naturais.

Conheci a Pedra de Xangô em agosto de 2014, na cerimônia de 
encerramento do I Seminário para Preservação do Patrimônio Cultural Compartilhado entre o Brasil e a Nigéria, quando o Alaafin de Oyo, Obá Lamidi Olayiwola Adeyemi III, esteve em Salvador. Visitei o local pela segunda vez, em um momento mais tranqüilo, para assistir a uma aula pública sobre o seu valor histórico, com a pesquisadora Maria Alice Pereira da Silva. Lembro que a platéia, em sua maioria, era de estudantes do ensino fundamental da rede pública de ensino. A intenção da palestrante era despertar na juventude a importância da cidadania e da proteção do patrimônio cultural e histórico.

Em outros momentos encontrei-a participando de eventos de temática étnico-racial ou fazendo palestra sobre o seu objeto de estudo. E agora chegou a oportunidade de brindar com a autora Maria Alice Pereira da Silva o lançamento dessa publicação intitulada Pedra de Xangô, um lugar sagrado afro-brasileiro na Cidade de Salvador. Oportuno e instrutivo, o livro originou-se da pesquisa de mestrado desenvolvida pelo Programa de Pós-Graduação em Arquitetura e Urbanismo da Universidade Federal da Bahia (PPGAU-UFBA). A edição objetiva o reconhecimento da história da Pedra de Xangô e da comunidade remanescente do Quilombo Buraco do Tatu.

Trata-se de uma pesquisa etnográfica, na modalidade observação participante, em diálogo permanente com a filosofia, antropologia e outras fontes documentais, bibliográficas, audiovisuais e orais. Graduada e especializada em Direito, consultora jurídica com experiência nas áreas de direitos humanos, relações étnico-raciais e políticas públicas, a pesquisadora apresenta um estudo que trouxe inquietação aos meios acadêmico, político e religioso da cidade. Certamente, não só para evitar o esquecimento silencioso dos arquivos e das bibliotecas, mas pela oportunidade, o texto da pesquisa também serviu de apoio ao processo do recente tombamento do monumento geológico e transformação da área do entorno na primeira Área de Proteção Ambiental (APA) e no primeiro parque em rede do município, conforme projeto em andamento.

O motivo da pesquisa consiste na reparação de parte da história da cidade caracterizada pelo seu relevo de cumeadas, aspecto que facilitava a criação de comunidades de quilombo no período colonial. Nesse sentido, o livro revela o quadro de herança da cultura escravista em que vive a população negra da primeira capital do país que, por sua vez, foi o último a abolir oficialmente a 
escravidão nas Américas. Assim, apresenta o cenário de um momento atual da expansão urbana de Salvador.

Em seis capítulos, o livro traz uma série de dados que enfatiza e reitera a luta das comunidades de terreiro pela preservação da Pedra de Xangô, já tida como santuário antes de ser descoberta pelo governo com suas intervenções de política habitacional. A autora lança mão de larga epistemologia para teorizar a utilidade ritual da pedra e seus desdobramentos a partir de outras civilizações, inclusive as africanas.

A partir do conceito de diáspora, a autora começa o relato tentando explicar a origem da pedra como elemento religioso em alguns contextos. Uma vasta revisão bibliográfica acompanha sua intenção de justificar a importância do seu objeto de estudo até chegar à ressignificação da Pedra do Buraco do Tatu, conforme revela nos três primeiros capítulos. Maria Alice Pereira da Silva é testemunha ocular de uma paisagem verde desaparecida no local onde nasceu e cresceu. Seus familiares eram comerciantes e produtores agropastoris da região. Por isso, elaborou uma narrativa própria e foi para este lugar que confessa no texto ter voltado para resgatar uma história.

O livro segue com um breve panorama histórico da região de Cajazeiras, a partir da política habitacional do governo e desapropriação de várias fazendas, até os choques e tensões após o surgimento da Pedra de Xangô. A faixa territorial em estudo localiza-se na zona nordeste de Salvador, cercada pelos bairros do Aeroporto, Itapuã, Mussurunga, e pela rodovia BR-324. A criação oficial do conjunto habitacional de Cajazeiras data de 1975, porém, a autora confere em levantamentos que a ocupação local vem desde os anos 1930/40 com os primeiros terreiros de candomblé.

Uma discussão interessante aparece no terceiro capítulo: a relação estabelecida pelos terreiros da região com a Pedra de Xangô. E dentre algumas considerações, percebe-se um processo de autorreconhecimento e afirmação de identidade em torno do espaço sagrado. Trata-se de uma questão de relação identitária ou de assimilação cultural? Quem atribuiu o pertencimento da pedra? Que discurso epistêmico define esse vínculo a uma divindade? Sem atender a essas questões e apesar da fundamentação teórica, o estudo traz a perspectiva de um espaço ressignificado a partir das práticas rituais que as comunidades de terreiro 
adotaram no local como ponto de referência. E assim, a autora deu prova de fôlego no seu trabalho de campo ao visitar e acompanhar o calendário de atividades de todos os terreiros de Cajazeiras que realizam rituais para Xangô.

No quarto capítulo, intitulado "Tecendo Redes de Resistência", a autora aborda sobre a manifestação da Caminhada da Pedra de Xangô, que reúne, todo mês de fevereiro, representantes de terreiros e de entidades civis. A comunidade reivindica que o local seja tombado como patrimônio histórico cultural, um espaço sagrado do candomblé, que seja preservado como símbolo de identidade e repassado às gerações futuras. Com base em suas observações e avaliações, a autora é precisa: "Não existe qualquer compromisso com o patrimônio cultural material e imaterial afro-brasileiro de Salvador". (p. 110)

Nos dois últimos capítulos, o discurso narrativo chama a atenção para o seminário "Pedra de Xangô: território sagrado". Do seu lugar de fala de advogada, a pesquisadora faz uso dos vários dispositivos legais existentes para discutir a importância do reconhecimento de espaços sagrados como patrimônio cultural e histórico. Revela ainda que apesar da legislação brasileira avançada, não há diálogo entre os órgãos públicos e gestores responsáveis pela salvaguarda patrimonial. E assegura que quando isso acontece é de forma fragmentada.

De forma satisfatória, o estudo realizado fortaleceu uma ação mais efetiva junto à pressão das comunidades de terreiro para a criação da APA Municipal Vale Assis Valente e o Parque em Rede Pedra de Xangô. A autora cita que no programa de seu curso foi possível implementar atividades em forma de projetos e seminários para denunciar a degradação das áreas verdes da cidade de Salvador. E conclui que a criação de uma APA e um parque não é conquista gratuita, e sim resultado da força dos movimentos sociais.

Essa imponente pesquisa, agora publicada em livro, deve provocar ainda grandes discussões a respeito das próximas etapas do trabalho de construção da APA e do parque em rede. Com isso, segue a perspectiva de preservação, na forma de resistência, em defesa do legado afro-brasileiro e seu desenvolvimento na diáspora, através de outras possíveis propostas sobre o monumento da Pedra de Xangô.

A leitura do livro deixa a certeza de que a pesquisa produzida cumpre sua função social dentro e fora das discussões acadêmicas, especialmente junto 
àqueles que necessitam de uma política pública para garantir um lastro mínimo de cidadania. Com isso, o estudo apresentado reforça a importância do trabalho de campo, do fazer etnográfico, como procedimento de investigação.

\section{REFERÊNCIA BIBLIOGRÁFICA}

SILVA, Maria Alice Pereira da. Pedra de Xangô: um lugar sagrado afro-brasileiro na cidade de Salvador. Recife: Liceu, 2019. 157 p.

Marcos Rodrigues: Mestre em Estudos Étnicos e Africanos e Bacharel em Comunicação pela Universidade Federal da Bahia, autor de textos em jornais impressos e revistas eletrônicas. Autor do texto O lugar e a pesquisa: relato de uma experiência de campo em Praia Grande (Illha de Maré) in: SANTOS, Jocélio Teles dos. Discutindo Etnicidades. Salvador: Edufba, 2014, p. 43-67.

(C) $(0)$ This work is licensed under a Creative Commons Attribution 4.0 International License.

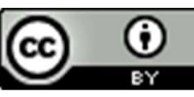

Este trabalho está licenciado com uma Licença Creative Commons - Atribuição 4.0 Internacional.

Artigo recebido para publicação em: 13 de abril de 2020.

Artigo aprovado para publicação em: 15 de abril de 2020. 